ENTREPRENEURSHIP AND SUSTAINABILITY ISSUES

ISSN 2345-0282 (online) http://jssidoi.org/jesi/ 2019 Volume 7 Number 1 (September)

http://doi.org/10.9770/jesi.2019.7.1(48)

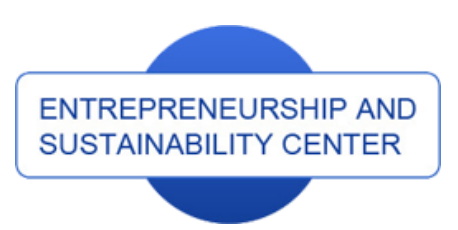

Publisher

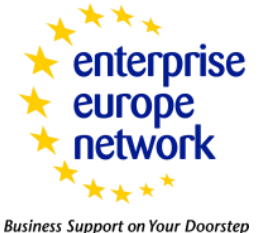

CASPA

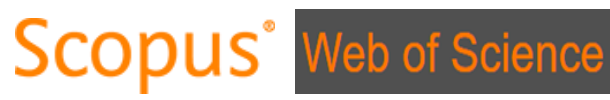

$\underline{\text { http://jssidoi.org/esc/home }}$

Business Support on Your Doorstep

\title{
CORRUPTION AS AN OBSTACLE TO SUSTAINABLE DEVELOPMENT: A REGIONAL EXAMPLE
}

\section{Irina Frolova ${ }^{1 *}$, Olga Voronkova ${ }^{2}$, Natalia Alekhina $^{3}$, Irina Kovaleva ${ }^{4}$, Natalia Prodanova ${ }^{5}$, Liudmila Kashirskaya ${ }^{6}$}

\author{
${ }^{1}$ Kazan Innovative University named after V.G. Timiryasov, Moskovskaya Street 42, Kazan, Russia \\ ${ }^{2}$ Altai state University, Lenina Street 6, Barnaul, Russia \\ ${ }^{3}$ I.M. Sechenov First Moscow State Medical University of the Ministry of Health of the Russia, Trubetskaya Street 8/2, \\ Moscow, Russia \\ ${ }^{4}$ Altai state agricultural University, Krasnoarmeysky Avenue 98, Barnaul, Russia \\ ${ }^{5}$ Plekhanov Russian University of Economics, Stremyanny Lane 36, Moscow, 117997, Russia \\ ${ }^{6}$ Financial University under the Government of the Russian Federation, Leningradsky Prospekt 49, Moscow, Russia
}

E-mail:*1 fii@mail.ru;

Received 14 March 2019; accepted 10 July 2019; published 30 September 2019

\begin{abstract}
Corruption in various sectors causes serious damage not only to individual economies, countries, and regions but also to humanity as a whole. This paper analyzes the state of corruption in the Republic of Tatarstan, the manifestations of which restrain the development of the Republic, and presents the results of a pilot sociological study that demonstrate changes in the perception of problems of corruption in society. The sustainable development of a region is influenced by various economic and social factors. The results of this research show that one of these factors is corruption, which is often used as a tool for managing territories at various levels. It is a serious obstacle to the achievement of continuous sustainable development of a region, as it impedes the building of harmonious relations between state, government, society, and business. Sustainable development of a region can be described as a system and as a process. In this study, "sustainable development" refers to the process in which various stakeholder interactions take place that influence the established order of relations in the region. The findings suggest that when assessing the effectiveness of a region's sustainable development, the level of corruption should be considered as an indicator of its stability. Some measures were proposed to improve the organization of anticorruption work in the Republic of Tatarstan for leveling social tensions in society.
\end{abstract}

Keywords: corruption, sustainable development, obstacle, Russia, Tatarstan

Reference to this paper should be made as follows: Frolova, I.; Voronkova, O.; Alekhina, N.; Kovaleva, I.; Prodanova, N.; Kashirskaya, L. 2019. Corruption as an obstacle to sustainable development: A regional example, Entrepreneurship and Sustainability Issues 7(1): 674689. http://doi.org/10.9770/jesi.2019.7.1(48)

JEL Classifications: D73, Q01, E26, E65

Additional disciplines law, sociology 


\section{ENTREPRENEURSHIP AND SUSTAINABILITY ISSUES}

ISSN 2345-0282 (online) http://jssidoi.org/jesi/

2019 Volume 7 Number 1 (September)

http://doi.org/10.9770/jesi.2019.7.1(48)

\section{Introduction}

Recently, research has focused on the sustainable development of territories and the influence of various factors on it (Baklanov, 2014; Malyutina, 2015; Ponomareva et al., 2019; Sasongko et al., 2018; Tvaronavičiené, 2018; Zeibote et al., 2019). For a long time at the global level, there has been an integrative influence of various socioeconomic problems on the sustainable development of territories. Sustainable development of a region is aimed at such development, which levels social tensions in society, sufficiently satisfies its needs, and ensures the stable economic growth of the territory. Corruption is one of the main social factors impeding the sustainable development of a territory.

The relevance of the study is due to changes in public perceptions about the role and causes of corruption, its development, and manifestations, as well as an assessment of the effectiveness of measures in the implementation of anti-corruption policy in Tatarstan. A number of authors (Asaliev et al., 2014; Badrutdinov and Rakhimov, 2013; Yeparkhina, 2013; Kochurova, 2017; Lipatov et al., 2017; Nagimov and Nagimov, 2015; Poltaradneva and Goverdovskaya, 2014; Savchenko et al., 2018; Papakostas, 2016) point to the need to measure the level of corruption among the population, the importance of anti-corruption monitoring (Kabanov, 2012; Pankratov, 2011; Saltykova, 2018; Feschenko, 2014; Shumakova et al., 2016), pay attention to corruption in various authorities and spheres of activity and anti-corruption measures (Vlasenko, 2015; Volkonskaya, 2018; Garipov et al., 2014; Golubovsky and Sinyukova, 2015; Dyatlov and Isakova, 2018; Eli, 2016; Kochurova, 2017; Temnikov, 2017; Frolova and Bibarsova, 2017; Chaldayeva et al., 2014; Luzgina 2017). Special attention should be paid to the works of researchers of the case study of the Republic of Tatarstan (Badrutdinov and Rakhimov, 2013; Garipov et al., 2014; Kochurova, 2017; Pankratov, 2011; Temnikov, 2017).

At first glance, the terms "sustainable" and "development" can be interpreted as bipolar definitions. Thus, sustainability implies some kind of stability or constancy, and "development" indicates a change or a process. Therefore, the symbiosis of definitions of "sustainable development" is interpreted as a constant change and continuous improvement (today is better than yesterday, and tomorrow is better than today). In this regard, sustainable development should be considered as a basis in territorial management strategies (Pavlyuk et al., 2018; Voronkova et al., 2019; Prodanova et al., 2019a; Goloshchapova et al., 2018; Fedorinin and Zhuravlev, 2002; Ivanova et al., 2018).

In order to assess the state of corruption in the Republic of Tatarstan, a pilot study was conducted in which 400 respondents aged from 19 to 65 took part, including: from 19 to $29-27.5 \%$; from 30 to $39-23.25 \%$; from 40 to $49-27.75 \%$; over $50-21.5 \%$. Most of the respondents are women $(68.25 \%)$.

Object of study: the attitude of the population of the Republic of Tatarstan toward various manifestations of corruption and the assessment by the society of the measures that are being taken to combat corruption in the Republic of Tatarstan.

The subject of the study is corruption as a factor of obstacles to the sustainable development of the region.

Objectives of the study:

1. To conduct a review of scientific research on the problem of corruption and sustainable development of territories.

2. To analyze the results of the questionnaire survey on the causes of corruption crimes, the degree of corruption of officials in various fields, the attitude of the population to the manifestations of corruption in the Republic of Tatarstan, to interpret the research results.

3. Formulate conclusions and develop recommendations for improving the organization of anti-corruption work in the Republic of Tatarstan to ensure the sustainable development of the region.

The following hypotheses are put forward: 


\section{ENTREPRENEURSHIP AND SUSTAINABILITY ISSUES}

ISSN 2345-0282 (online) http://jssidoi.org/jesi/

2019 Volume 7 Number 1 (September)

http://doi.org/10.9770/jesi.2019.7.1(48)

- various manifestations of corruption together have a serious impact on the sustainable development of the region, the growth of social tension in society and the negative perception of anti-corruption measures;

- increasing the level of anti-corruption education and changing the anti-corruption behavior of the population of the Republic of Tatarstan.

The research results are of an applied nature and can be used as the basis for the development of a separate region development strategy, as well as programs of interaction between civil society institutions and authorities on anticorruption education and anti-corruption issues to ensure sustainable development of the territory and leveling social tension.

\section{Literature review}

Corruption is always a companion of new regimes, so the article (Barsukova, 2019) traces the transformation of informal relations between the state and big business due to changes in the financial and administrative capabilities of the state, and compares the situations of the 1990s, 2000s and 2010s. However, corruption is a problem in many countries (Pujiyono et al., 2019; Campbell, 2018; Denkers, 2018; Naushad et al., 2018; Kordík and Kurilovská, 2018; Osipov et al., 2018; Petukhov et al., 2017; Batzilis, 2019). Of particular interest is a study of China's experience that measures the impact of anti-corruption efforts on public perceptions of corruption and trust in government (Zhang et al., 2019; Gulkov et al., 2019). Based on data from twelve Chinese provinces, anticorruption efforts, public perceptions of corruption, and government credibility are used as variables in the empirical framework, and then analyzed with a detailed discussion of the impact of the fight against corruption. The results show that public perception of corruption affects the attitude to the authority of the government, anticorruption efforts mitigate the damage in public confidence in the central government, but do not significantly reduce the damage in trust to the provincial governments. Based on the results, three political consequences emerge: (1) anti-corruption efforts should be further improved as an important method of maintaining the health of the ruling party and as a method of winning public support (Prodanova et al., 2019b; Sharafutdinov et al., 2019); (2) the government should increase diversification of efforts to curb corruption, introduce innovative anticorruption mechanisms (Zhuravlev et al., 2018; Mullins, 2019; Korableva et al., 2019; Ige, 2019; Ilyina et al., 2019) and increasing public participation in anti-corruption efforts, and (3) measures to combat corruption should be strengthened.

\section{Methods}

The study was conducted by a questionnaire survey in various cities of the Republic of Tatarstan. The questionnaire included 29 questions aimed at studying and analyzing the causes of corruption crimes, the degree of corruption of officials in various spheres, the public attitude toward corruption, and public assessment of the measures taken to combat corruption in the Republic of Tatarstan.

Sampling for the questionnaire survey consisted of two stages. At the first stage, four settlements in the Republic of Tatarstan were selected: Kazan, Naberezhnye Chelny, and Almetyevsk as the largest cities in terms of population, and for comparison - Nizhnekamsk, as the youngest city in the Republic. Then there was a sampling of respondents based on traditional selection criteria: age and gender, as well as the employment status (student, employed, unemployed). The pilot survey was conducted in large shopping centers. The method of data collection was based on the willingness of respondents to independently answer all the questions of an anonymous questionnaire on the research problem. The collection of survey data made it possible to process and systematize the information received. In the processing of empirical data, the authors used the methods of typology, ranking, grouping, and comparative analysis. 


\section{Data Collection}

The empirical basis of the study was a secondary analysis of research data on corruption and sustainable development, as well as the results of own sociological research.

The sample survey consisted of 400 respondents aged from 19 to 65 years, including: from 19 to $29-27.5 \%$; from 30 to $39-23.25 \%$; from 40 to $49-27.75 \%$; over $50-21.5 \%$. Most of the respondents are women $(68.25 \%) .69 \%$ of respondents are employed, $8.5 \%$ are in search of a job, $4.25 \%$ of respondents are unemployed. $18.25 \%$ of survey participants study at educational institutions of the Republic; some of them also combine work and study.

For half of the participants in the sociological survey (51.5\%), corruption is a significant problem, $27.75 \%$ attribute it to extremely acute problems, for $15.75 \%$ of respondents this problem is insignificant, and for $5 \%$ this is not a problem at all. Among respondents, 102 people (25.5\%) are residents of Kazan, 160 people (40\%) live in Naberezhnye Chelny, 80 respondents (20\%) are residents of Nizhnekamsk and 58 (14.5\%) live in Almetyevsk.

According to the results of a concrete sociological study, the population classifies as corruption various acts. Most of the participants consider the following actions: receiving a bribe (92\%), giving a bribe (86\%); a crime committed by an official for personal gain in personal interests, in the interests of other persons/organizations (75\%), and any crime committed by an official using his/her official position (74.25\%).

The lowest grades of corruption have been received for the following: giving gifts to officials; any crime committed by an official and provision of any lawful services by an official $-9.5 \%, 6 \%$, and 5\%, respectively. The main goals of giving a bribe to an official are presented in Table 1.

Table 1. Opinion of the respondents on the purpose of giving a bribe (\%)

\begin{tabular}{|c|c|}
\hline The purpose of giving a bribe & $\%$ \\
\hline 1) violate the established procedure for resolving issues in their own interests (the desire to circumvent the law) & 24,25 \\
\hline 2) solve the problem with government representatives in their favor & 52 \\
\hline 3) escape responsibility for committing wrongdoing & 37,75 \\
\hline 4) get any help, including illegal (get benefits) & 25,25 \\
\hline 5) conniving at work (close eyes to improper fulfillment of official duties) & 14,5 \\
\hline 6) promotion (assistance in rapid advancement on the career ladder) & 15,25 \\
\hline 7) patronage of service (unreasonable appointment to a higher position) & 12,5 \\
\hline 8) meet personal needs that are expressed in obtaining certain benefits or benefits & 36,75 \\
\hline 9) meet the interests of third parties & 11,5 \\
\hline $\begin{array}{l}\text { 10) for the purpose of gratitude to the official unforeseen by law, advance due remuneration for already } \\
\text { committed lawful action in service }\end{array}$ & 15,25 \\
\hline $\begin{array}{l}\text { 11) for the purpose of remunerating the official after the commission of a specific action (inaction) in favor of } \\
\text { the bribe giver }\end{array}$ & 11 \\
\hline $\begin{array}{l}\text { 12) for the purpose of bribing (for committing (evading from committing) a particular action in the interests of } \\
\text { the briber) }\end{array}$ & 35 \\
\hline 13) Hard to answer & 5,25 \\
\hline
\end{tabular}

Source: own research

According to the respondents, the main objectives for which people resort to giving a bribe to an official are the following:

- $\quad$ solving the problem with representatives of public authorities in their favor $-52 \%$;

- avoiding responsibility for committing unlawful actions $-37.75 \%$; 
ENTREPRENEURSHIP AND SUSTAINABILITY ISSUES

ISSN 2345-0282 (online) http://jssidoi.org/jesi/

2019 Volume 7 Number 1 (September)

http://doi.org/10.9770/jesi.2019.7.1(48)

- meeting personal needs, which are expressed in obtaining certain preferences or benefits $36.75 \%$;

- committing/evading from committing a particular action in the interests of the briber $-35 \%$.

Rarely, people resort to giving a bribe to an official with the goal of satisfying the interests of third parties $(11.5 \%)$ and remunerating an official after he/she has committed a certain action (inaction) in favor of the briber $11 \%$.

It should be noted that out of 208 people who indicated a solution to the problem with representatives of state authorities in their favor, 94 respondents are from Kazan (92.12\% of the Kazan sample) and 104 people from Naberezhnye Chelny (65\% of the Naberezhnye Chelny sample).

The main causes of corruption crimes, according to residents of the Republic of Tatarstan, are: insufficient control over the activities of officials, poorly identifying corruption crimes (52\%), insufficient effectiveness of punishment for corruption crimes (50.75\%), imperfect laws, leading to the appearance of officials, using loopholes for personal gain $(31 \%)$.

$36.25 \%$ of respondents believe that the opinion in the team does not matter for the commission of a corruption offense by an official.

To a large extent, officials agree to bribe because of self-interest (51.5\%), confidence that they will go unpunished $(48.25 \%)$, insecurity in material well-being in the future $(35 \%)$, as well as the corruption of the very system of authorities (30\%). The reasons for extortion of a bribe by officials are also largely due to self-interest (62\%), confidence in impunity (52.5\%), and difficult financial situation $(35.5 \%)$.

With regard to anti-corruption measures in the Republic of Tatarstan, it is possible to state a positive attitude of the population: more than half of respondents believe that giving a bribe $(54.5 \%)$ can be avoided to solve their own problems, $28.5 \%$ of respondents indicate the need to avoid it. Only $15 \%$ of survey participants consider bribes a necessary part of life.

Meantime, respondents are more convinced (56\%) that without a bribe, problems are not solved or are solved with great difficulties.

\section{Data Analysis}

The main elements of the analysis were chosen as follows: the attitude of the population toward corruption, opinions on the level of corruption of various authorities and areas of activity, the presence of corruption situations in the life of respondents, the attitudes toward publications in the media about corruption, the opinion of respondents about the effectiveness of measures to combat corruption.

First, it is necessary to analyze the results obtained regarding the attitude of the respondents toward corruption (see Fig. 1).

Only $44 \%$ of respondents show a sharply negative and a negative attitude toward corruption (see Fig. 1). $43 \%$ indicated a tolerant or neutral attitude toward manifestations of corruption, and $7 \%$ referred to it positively. 


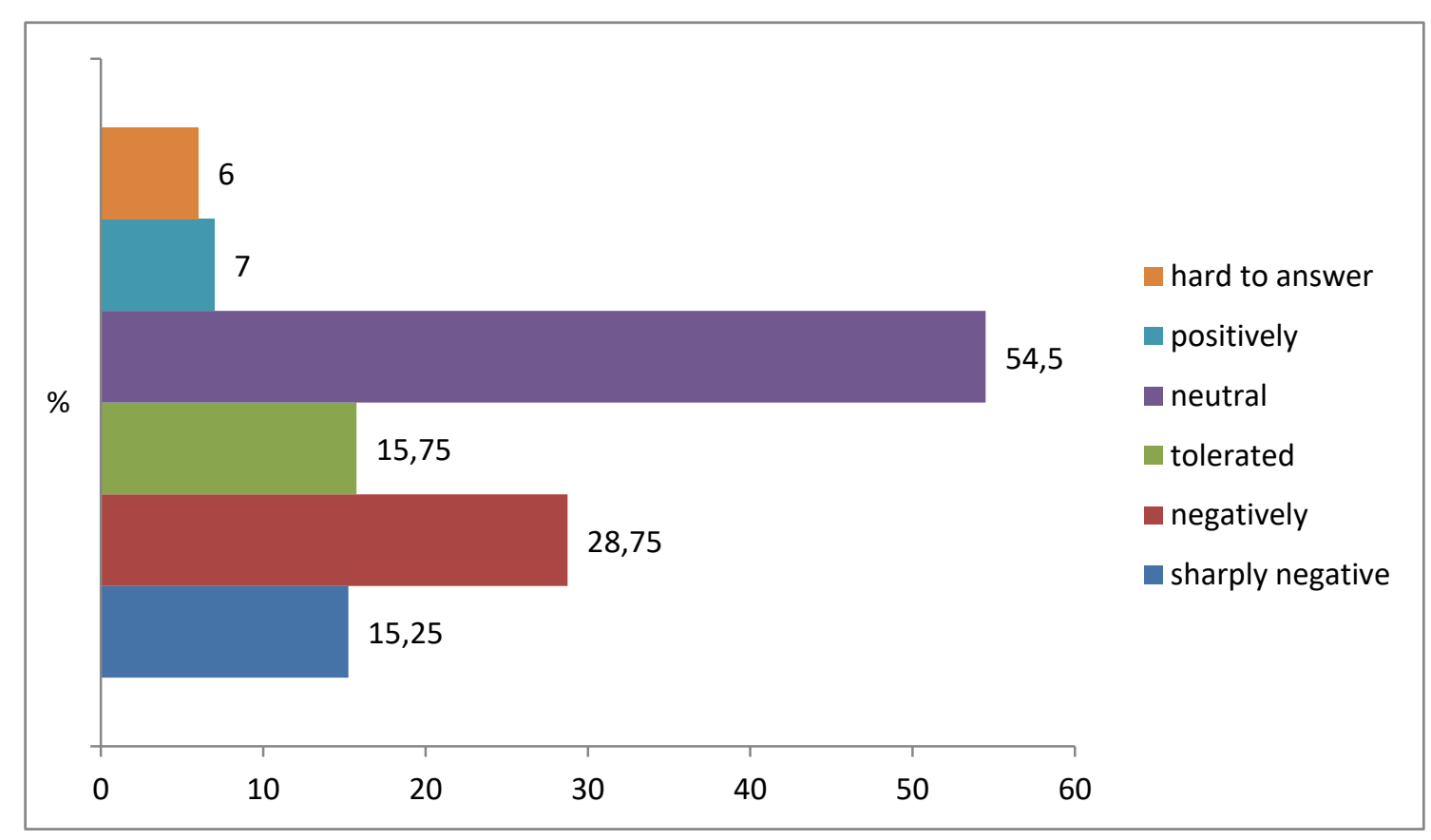

Fig. 1. Attitudes of respondents toward corruption (\%) Source: own research

When assessing the level of corruption of various authorities and spheres of activity, it was found that the majority of respondents noted the highest degree of corruption in the traffic police (76\%), the housing $(76.25 \%)$, the prosecutors $(75.75 \%)$, the public administration $(75.25 \%)$, and the police (74\%) (see Fig. 2).

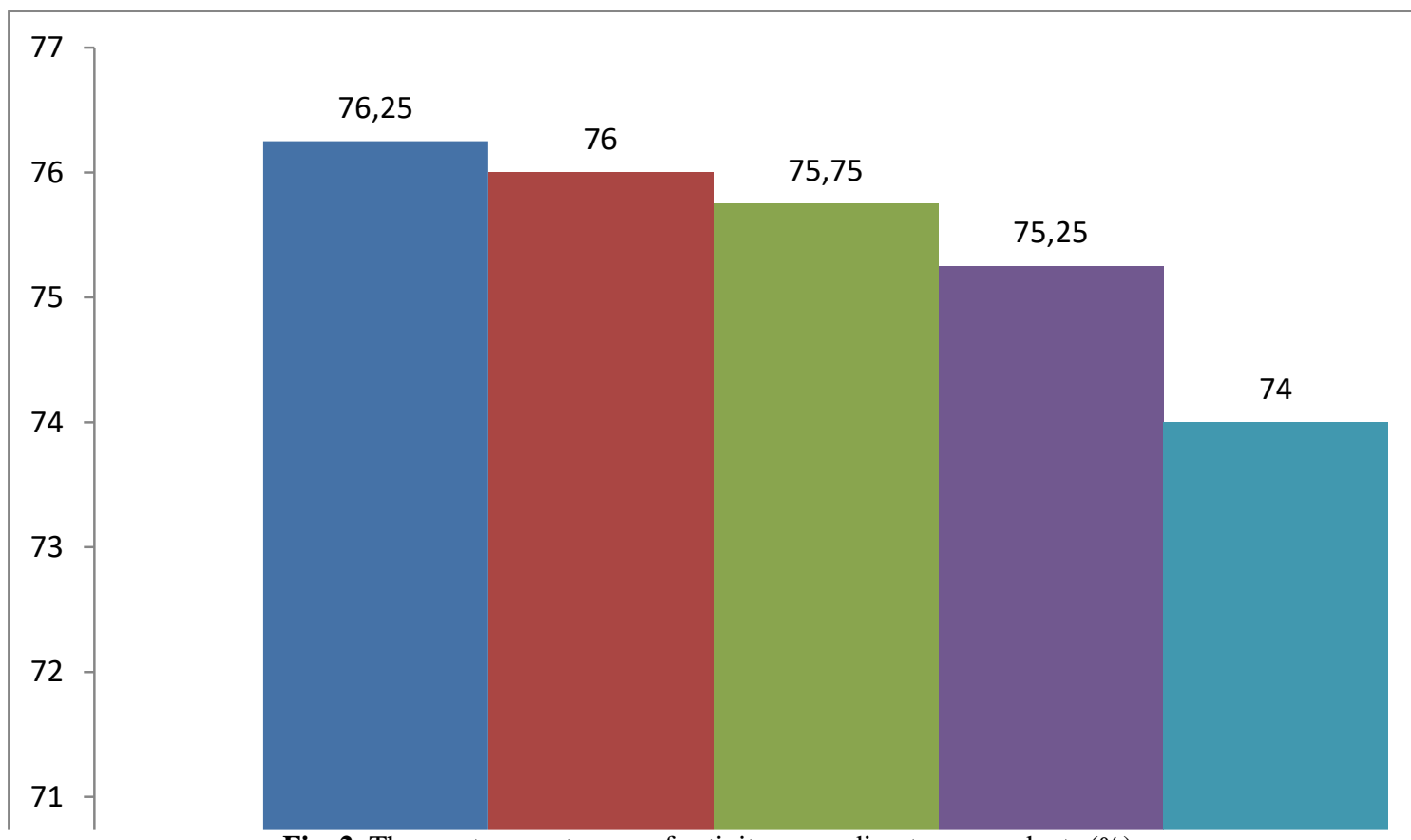

Fig. 2. The most corrupt areas of activity, according to respondents (\%)

Source: own research 


\section{ENTREPRENEURSHIP AND SUSTAINABILITY ISSUES}

ISSN 2345-0282 (online) http://jssidoi.org/jesi/ 2019 Volume 7 Number 1 (September) http://doi.org/10.9770/jesi.2019.7.1(48)

In addition to individual responses, the respondents identified a high level of corruption in the military sphere (4\%) and the Russian Orthodox Church (2.75\%). The respondents allowed a low level of corruption in the drug control bodies (40.75\%), the consumer rights protection authorities $(40.5 \%)$ and the Federal Security Services (FSB) $(29.75 \%)$. Some respondents still admit the absence of corruption in the FSB $(7.25 \%)$, the investigative bodies $(5.25 \%)$, in the sphere of culture and sports (4\%), the municipal services $(3.5 \%)$, the prosecutors $(3 \%)$, the police $(1 \%)$, as well as in the economic sphere $(0.5 \%)$ and the traffic police $(0.25 \%)$. It should be noted that all survey participants believe that to one degree or another, corruption is present in the legislative and judicial bodies and the political sphere. Thus, more than half of the respondents (56.5\%) point out a high level of corruption in the political sphere.

In terms of increasing the social tension of the population, there are also concerns about the results of the fact that $51.75 \%$ of respondents assess with a high level of corruption the investigative bodies, $48 \%$ - the legislative and registering bodies, $47.5 \%$ - judicial bodies, a quarter of respondents $(26.5 \%)$ indicate a high degree of corruption in the FSB. A high level of corruption in the business sphere $(50.75 \%)$, in the tax authorities $(46.75 \%)$, in the education $(40.75 \%)$ and the economic sphere $(34.5 \%)$ potentially cause the low growth of the Republic's economy due to the development of the business environment and entrepreneurial competencies. This state of affairs hampers the economic development of the territory, thereby reducing its competitiveness. Mostly, when a crime of corruption is committed, respondents condemn the one who extorts a bribe $(52.25 \%)$, and $40 \%$ equally condemn all (the extortionist, briber and intermediary).

Over the past 2 years, 339 people out of the number of respondents $(84.75 \%)$ got into corruption situations, which were more related to the traffic police $(57.42 \%)$, healthcare $(29.58 \%)$, and education $(13.34 \%)$. Of the 12 people who refused to give a bribe, the main reason (66.64\%) was the "not affordable" amount of the bribe, only one person said about his principled attitude not to give a bribe. The population believes that publications in the media about facts of corruption mostly pursue political goals - to remove a competitor, an "inconvenient" person, etc. $(93.75 \%)$ and clearly aim to create for people a picture of a successful fight against corruption, regardless of its results $(87.25 \%)$. Only $6.5 \%$ of respondents rated the objectivity of the information in the media about the fight against corruption at maximum points, and $32.25 \%$ of the participants in the survey put the minimum points for this indicator. This more testifies to the populism of coverage of anti-corruption issues in the media than to the real picture of the current state of affairs.

From the point of view of survey participants, the most effective measures to combat corruption (maximum effectiveness of 4-5 points) are the following (see Table 2):

- use technical means to openly see the activities of officials $-96.25 \%$;

- verification of the accuracy and completeness of information on income, property and property obligations represented by officials, their spouses and minor children $-91 \%$;

- public control over the activities of officials - 90\%;

- strengthening state control over the activities of officials $-88.5 \%$;

- criminal prosecution and punishment without any exceptions $-88.5 \%$;

- toughening criminal penalties for corruption $-83.75 \%$;

- free access to public services $-80.75 \%$; 
- formation of intolerance in society towards corrupt behavior $-63.25 \%$;

- improvement of legislation, effective implementation of existing regulations $-60 \%$;

- reduction in the number of state and municipal employees $-53.25 \%$.

Table 2. The effectiveness of measures to combat corruption, according to respondents (\%)

\begin{tabular}{|c|c|c|c|c|c|}
\hline Anti-Corruption Measures & 1 point & 2 points & 3 points & 4 points & 5 points \\
\hline $\begin{array}{c}\text { Improving legislation, effective implementation of } \\
\text { existing laws }\end{array}$ & 10,75 & 14,25 & 15 & 18 & 42 \\
\hline $\begin{array}{c}\text { Encourage a long, flawless and efficient performance } \\
\text { of official duties }\end{array}$ & 41,25 & 22,75 & 35 & 1 & - \\
\hline $\begin{array}{c}\text { Strengthening state control over the activities of } \\
\text { officials }\end{array}$ & 0,25 & 2 & 9,25 & 16 & $\mathbf{7 2 , 5}$ \\
\hline Providing public control over the activities of officials & 3,75 & 3,25 & 3 & 14,5 & $\mathbf{7 5 , 5}$ \\
\hline Increased penalties for corruption & 4,25 & 4,75 & 7,25 & 26 & $\mathbf{5 7 , 7 5}$ \\
\hline $\begin{array}{c}\text { Wider coverage of anti-corruption activities in the } \\
\text { media }\end{array}$ & - & 5 & $\mathbf{5 3 , 7 5}$ & 32,75 & 8,5 \\
\hline $\begin{array}{c}\text { Formation of social intolerance towards corrupt } \\
\text { behavior }\end{array}$ & 1 & 10,25 & 25,5 & 28,75 & 34,5 \\
\hline Free access to public services & 3,5 & 6,25 & 9,5 & 30,25 & $\mathbf{5 0 , 5}$ \\
\hline $\begin{array}{l}\text { Providing citizens with access to information about the } \\
\text { activities of federal government bodies, including the } \\
\text { subjects of the Russian Federation and local } \\
\text { governments }\end{array}$ & 5 & 35,75 & 31 & 26,25 & 2 \\
\hline Open decision-making by government representatives & 15,25 & 18,25 & 24,5 & 36 & 6 \\
\hline $\begin{array}{c}\text { Reducing the number of state and municipal } \\
\text { employees }\end{array}$ & 23 & 18 & 5,75 & 23 & 30,25 \\
\hline Increase in material and social security of officials & 31 & 40,5 & 22,5 & 2 & 4 \\
\hline $\begin{array}{l}\text { In the case of a crime to prosecute and punish without } \\
\text { exception }\end{array}$ & 3,5 & 5,25 & 2,75 & 12,25 & 76,25 \\
\hline Conduct demonstration, exit trials of bribe takers & 8,75 & 9,75 & 46 & 17 & 18,5 \\
\hline $\begin{array}{l}\text { Use technical means of openly monitoring the } \\
\text { activities of officials }\end{array}$ & 0,5 & 2,5 & 0,75 & 45,5 & 50,75 \\
\hline $\begin{array}{c}\text { Development of institutions of public and } \\
\text { parliamentary control over compliance with legislation } \\
\text { on countering corruption }\end{array}$ & 8 & 26 & 60,25 & 4 & 1,75 \\
\hline $\begin{array}{c}\text { Presentation of qualification requirements for citizens } \\
\text { applying for filling positions of state or municipal } \\
\text { service }\end{array}$ & 15,25 & 28,5 & $\mathbf{5 1 , 2 5}$ & 2,25 & 2,75 \\
\hline $\begin{array}{c}\text { Verification of the accuracy and completeness of } \\
\text { information about income, property and property } \\
\text { obligations represented by officials, their spouses and } \\
\text { minor children }\end{array}$ & 1,75 & 1 & 6,25 & 13,25 & $\mathbf{7 7 , 7 5}$ \\
\hline
\end{tabular}

Source: own research

The measures of a moderate degree of effectiveness ( 3 points) in the fight against corruption are the following: - development of institutions of public and parliamentary control over the observance of anti-corruption regulations $-60.25 \%$;

- wider coverage of anti-corruption activities in the media $-53.75 \%$; 
- introduction of qualification requirements for citizens applying for positions of state or municipal service $51.25 \%$.

$71.75 \%$ of respondents mentioned raising the material and social security of officials, as well as motivation for the continuous, flawless and efficient performance of duties by an official $(64 \%)$ as an ineffective measure to combat corruption.

The majority of respondents are positive about toughening criminal penalties for giving a bribe: $43.5 \%$ do not allow any doubt, and $52.25 \%$ are more positive than negative.

Of the economic penalties for corruption crimes, $94.75 \%$ of respondents consider confiscation, but not a fine, effective (see Table 3).

Table 3. The choice by respondents of effective penalties for corruption crimes (\%)

\begin{tabular}{|c|c|c|c|c|c|c|}
\hline Effectiveness of penalties & 1 point & 2 points & 3 points & 4 points & 5 points \\
\hline Confiscation & - & 1,75 & 3,5 & $\mathbf{1 5 , 5}$ & $\mathbf{7 9 , 2 5}$ \\
\hline Penalty & - & $\mathbf{2 5 , 7 5}$ & $\mathbf{5 4 , 7 5}$ & 19 & 0,5 & - \\
\hline \multicolumn{7}{|c|}{ Imperative } \\
\hline Long imprisonment & - & - & - & $\mathbf{9 , 5}$ & $\mathbf{9 0 , 5}$ \\
\hline The death penalty & 7 & 3,5 & 6,25 & $\mathbf{8 , 5}$ & $\mathbf{7 4 , 7 5}$ \\
\hline
\end{tabular}

Source: own research

Among the mandatory measures of punishment, $100 \%$ of those surveyed mentioned long-term imprisonment and 83.25\% - death penalty as the measures having maximum effectiveness. The results show that the population does not trust the solution of their questions by the authorities and the protest mood of the population, the lack of tolerance for power and the social tension of the society.

At the same time, answering the question about the acceptability of death penalty for committing a corruption offense, only $42.25 \%$ of the respondents were categorically against the death penalty, because it can become a way of getting rid of "undesirable" people, and corruption will still flourish.

\section{Discussion}

When analyzing the data obtained, a contradiction arises: the respondents consider the death penalty to be an effective punishment, but they show humanism in this connection.

One can see a negative attitude of the population regarding the prospects of fighting corruption in the next 3-5 years $-70.25 \%$ of respondents believe that the situation is unlikely to change. This may also be due to this reason: $65 \%$ or 313 survey participants are not ready to report corruption facts that have become known to them. Consequently, the population, to a greater extent, places the responsibility for fighting corruption on the authorities, demonstrating at the same time a low level of readiness to express their citizen stand and report on the fact of corruption.

Of the 87 people who are ready to report a crime of corruption, 37 people (42.55\%) will report to the prosecutor; $33.35 \%$ (29 people) to the anti-corruption commission and $24.15 \%$ (21 people) to the helpline.

According to the results of the survey, applying to the police, or via e-mail to the law enforcement agencies and to own leadership does not arouse confidence in the population. 
Table 4. Reasons for keeping silent about the facts of corruption (\%)

\begin{tabular}{|c|c|}
\hline Why do you think people with certain information do not report corruption? & $\%$ \\
\hline 1) consider it useless, still measures will not be taken & 43,5 \\
\hline 3) it is dangerous not only for them, but also for their loved ones due to possible negative consequences & 42,75 \\
\hline 2) they do not wish to bother themselves (to appear upon the call of the investigator, etc.) & 13,75 \\
\hline 4) do not consider it necessary, believing that this will inevitably become known to law enforcement agencies & 0 \\
\hline 5) difficult to answer & 0 \\
\hline
\end{tabular}

Source: own research

Survey participants name two main reasons why they do not report corruption: the futility is $43.5 \%$ and the presence of danger and negative consequences for families $-42.75 \%$.

Over the past 2 years, 18 people out of those polled have turned to law enforcement agencies about a corruption offense.

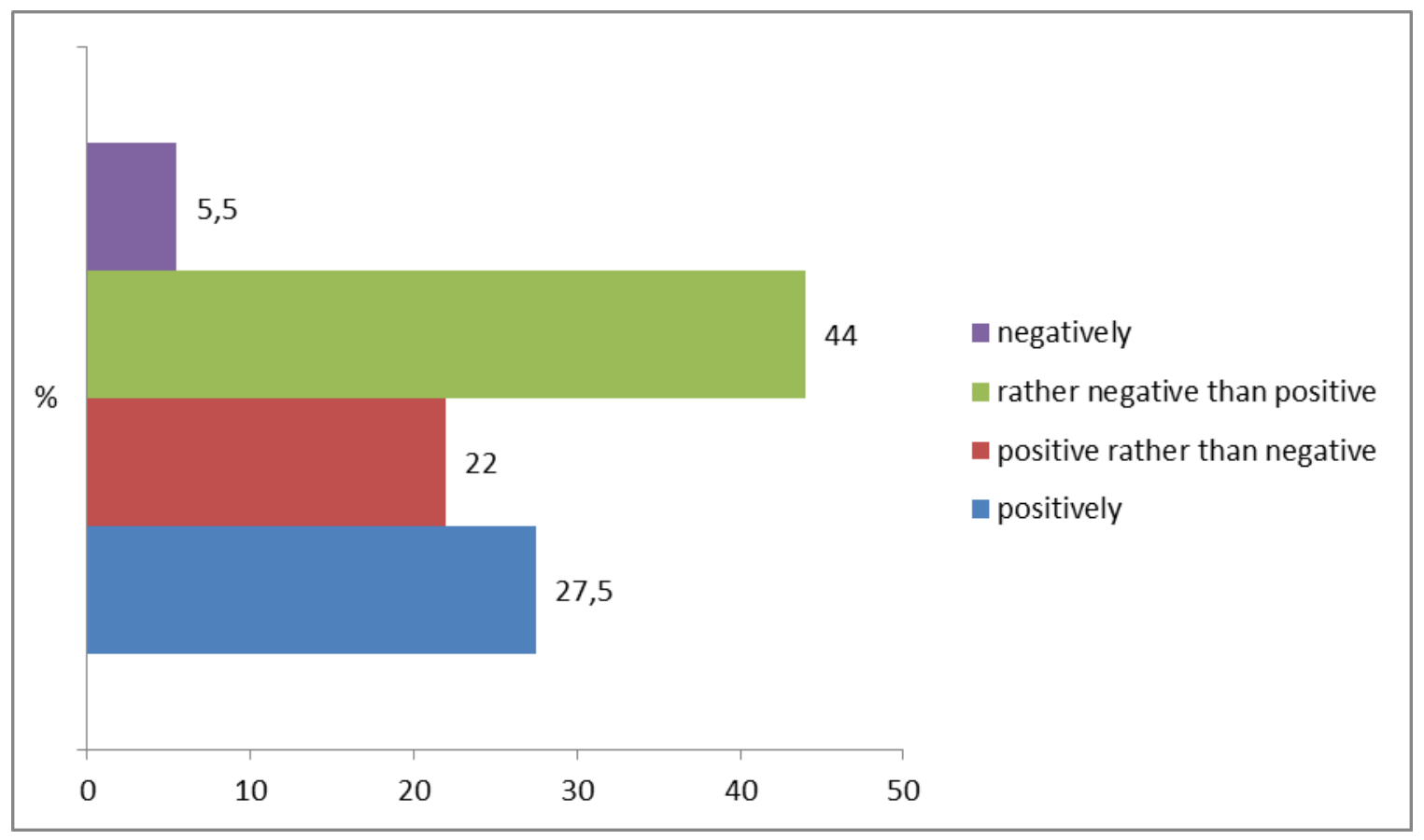

Fig. 3. Opinion of respondents about the attention shown to them by the law enforcement agencies when addressing the fact of corruption offense (\%)

Source: own research

$44 \%$ of them ( 8 people) rated the attention to them rather negatively than positively. $27.5 \%$ of respondents ( 5 persons) were completely satisfied with the attention to solving the problem.

The data on the possibility of exemption from criminal responsibility of participants in a corruption offense were also of interest. Thus, $87.75 \%$ of respondents believe that it is possible to exempt a bribe-giver from criminal liability in the following cases: existing extortion against him/her by an official; repentance and voluntary reporting of the incident to the internal affairs bodies (57.75\%) and rendering maximum assistance in solving the crime $(54.25 \%)$. The population is also quite loyal to the intermediary in a corruption offense and allows 


\section{ENTREPRENEURSHIP AND SUSTAINABILITY ISSUES}

ISSN 2345-0282 (online) http://jssidoi.org/jesi/

2019 Volume 7 Number 1 (September)

http://doi.org/10.9770/jesi.2019.7.1(48)

exemption from criminal liability in cases of active assistance in solving and/or stopping a crime (69.75\%) and voluntarily reporting to the authorized body on mediation in bribery $(63.5 \%)$.

A categorical "no" about the possibility of exemption from criminal responsibility was chosen by the respondents for the bribe-taker in cases if an official receives an offer from a briber (76\%) and repentance and voluntary reporting about the incident to the internal affairs bodies (67\%).

Thus, there is a duality and ambiguity of the respondents in relation to the various participants in a corruption offense. This may also be due to the insufficient level of anti-corruption training.

\section{Conclusions}

According to the results of the study, it is possible to formulate the following conclusions:

- there is an integrative effect of various socio-economic problems on the sustainable development of territories;

- corruption is one of the main social factors impeding the sustainable development of a region.

According to the results of a sociological study of the population in the Republic of Tatarstan, the hypotheses were confirmed that various manifestations of corruption have a serious impact on the sustainable development of the region, its economic growth, and hidden social tensions in society. The negative perception of anti-corruption measures was also confirmed, which confirms the low level of trust and the lack of tolerance of the population towards the authorities in solving problems of corruption.

The hypothesis of increasing the level of anti-corruption training and anti-corruption behavior of the population of the Republic of Tatarstan was partially confirmed: on the one hand, a positive change in the public's attitude to avoid giving a bribe; on the other hand, the negative attitude of the respondents based on the coverage of anticorruption issues in the media, which may be due to populism, rather than presenting a real picture of the current state of affairs. Further research is needed to identify the relationship between the level of corruption and indicators of the region's development effectiveness.

In order to improve the organization of anti-corruption work is proposed:

1. To continue the work on the formation of anti-corruption behavior among the population.

2. Develop mechanisms that provide opportunities to fearlessly report on the facts of corruption crimes and the protection of persons providing such information.

3. Organize work in the media to form a positive image of law enforcement agencies in the fight against corruption on a regular basis.

4. To ensure transparency of reporting on the fight against corruption in the law enforcement agencies themselves and the measures taken, to place information in the public domain.

5. Organize a transparent system of public feedback with the authorities throughout the vertical on issues of corruption.

6. Ensure a wide and open discussion on the websites of law enforcement agencies and official web pages on the problems of corruption, survey results, provide the opportunity to leave open reviews without the possibility of their removal with the creation of the tab "Fact of corruption".

7. To ensure discussion in the mass media of the role of civil society in the participation of public control in the field of combating corruption.

8. Develop and implement mechanisms for the use of various public control tools.

9. To ensure the conduct of public control on the basis of continuous analysis of indicators of public anticorruption monitoring. 


\section{ENTREPRENEURSHIP AND SUSTAINABILITY ISSUES}

ISSN 2345-0282 (online) http://jssidoi.org/jesi/ 2019 Volume 7 Number 1 (September)

http://doi.org/10.9770/jesi.2019.7.1(48)

10. Develop monitoring indicators for assessing the effectiveness of the region's sustainable development, incorporating the level of corruption as an indicator of sustainability.

11. Expand the pilot study toolbox to organize and conduct further integrated research together with economists to identify the correlation of the measured level of corruption with the economic indicators of the region's development.

\section{References}

Asaliev, A. M., Poltarykhin, A. L., \& Alkhimenko, O. N. (2014). Intellectual capital: Theory and approaches of its assessment on macro level. World Applied Sciences Journal, 30(10), 1404-1408. https://doi.org/10.5829/idosi.wasj.2014.30.10.14187

Badrutdinov, MS, Rakhimov, S.F. (2013) Interaction in the Republic of Tatarstan of state authorities and local authorities with civil society institutions on the implementation of anti-corruption policy and financial control. Actual problems of economics and law, (27), 227-234.

Baklanov, P.Ya. (2014) Territory of advanced development: concept, structure, approaches to the selection. Regional studies, 3: 12-19.

Barsukova, S. (2019). Informal practices of big business in the post-soviet period: From oligarchs to "kings of state orders". Demokratizatsiya, 27(1), 31-49.

Batzilis, D. (2019). Electoral competition and corruption: Evidence from municipality audits in Greece. International Review of Law and Economics, 59, 13-20. https://doi.org/10.1016/j.irle.2019.04.003

Campbell, L. (2018). The organisation of corruption in commercial enterprise: Concealing (and revealing) the beneficial ownership of assets. Corruption in commercial enterprise: Law, theory and practice (pp. 82-101) https://doi.org/10.4324/9781315105796

Chaldayeva, L.A., Kilyachkov, A.A., Sivakov, O.G. (2014). The role of the business community in the fight against corruption. Finance and credit, (617), 2-8.

Denkers, A. (2018). Mickey-mouse-money and gingerbread cookies: Bonuses and organizational measures as predictors of corruption in organizations. Corruption in commercial enterprise: Law, theory and practice (pp. 124-142) https://doi.org/10.4324/9781315105796

Dyatlov, G.A., Isakova, Yu.I. (2018) Spheres and forms of the spread of corruption. Science and education: economy and economics; entrepreneurship; right and management, 3(94), 92-96.

Eli, C.K. (2016) Analysis of the main trends of corruption crime in Russia. All-Russian Journal of Criminology, 10(3), $531-543$.

Fedorinin, V. N., \& Zhuravlev, P. V. (2002). New developments of optopolarization sensor devices and articles based on them. Paper presented at the Proceedings of SPIE - the International Society for Optical Engineering, 4900(2) 982-987. https://doi.org/10.1117/12.484491

Feschenko, P.N. (2014). Functioning of the anti-corruption monitoring system: quality improvement issues. Actual problems of economics and law, 1(29), 66-71.

Frolova, OV, Bibarsova, G.Sh. (2017). Corruption in modern Russia as a threat to state and public security. Humanitarian problems of military affairs, (11), 75-77.

Garipov, I.M., Kabanov, P.A., Magizov, R.R. (2014). Victimological measurement of the state of commercial corruption in the Republic of Tatarstan (analysis of statistical indicators for 2007-2011). Criminology: yesterday, today, tomorrow, 2(33), 51-56.

Goloshchapova, L. V., Plaskova, N. S., Prodanova, N. A., Yusupova, S. Y., \& Pozdeeva, S. N. (2018). Analytical review of risks of loss of profits in cargo transportation. International Journal of Mechanical Engineering and Technology, 9(11), 1897-1902.

Golubovsky, V.Yu., Sinyukova, T.N. (2015). Forms and types of corruption in the modern Russian society. Political linguistics, 2 (52), 240-246. 


\section{ENTREPRENEURSHIP AND SUSTAINABILITY ISSUES}

ISSN 2345-0282 (online) http://jssidoi.org/jesi/ 2019 Volume 7 Number 1 (September) http://doi.org/10.9770/jesi.2019.7.1(48)

Gulkov Yu.V., Turysheva A.V., Kopteva A.V. (2019). Research of Grounding Systems of Electrical Complexes in the Conditions of Permafrost Soils. Proceedings of the 2019 IEEE Conference of Russian Young Researchers in Electrical and Electronic Engineering, ElConRus pp. 969-972. https://doi.org/10.1109/EIConRus.2019.8657119

Ige, O. (2019). Using action learning, concept-mapping, and value clarification to improve students' attainment in ICT concepts in social studies: The case of rural learning ecologies. Journal of Social Studies Education Research, 10(1), 301-322.

Ilyina, I., Kulibanova, V., \& Teor, T. (2019). Special aspects of master data-based integrated management of region reputation in modern IT environment. Paper presented at the IOP Conference Series: Materials Science and Engineering, 497(1) https://doi.org/10.1088/1757$\underline{899 X / 497 / 1 / 012022}$

Ivanova, V. N., Atyukova, O. K., \& Poltarykhin, A. L. (2018). Prerequisites of growth of investment and social attractiveness of the regions of russia within the framework of implementation of the public-private partnership projects. International Journal of Mechanical Engineering and Technology, 9(11), 2299-2305.

Kabanov, P.A. (2012) Criminological monitoring of the interaction of public authorities of the constituent entities of the Russian Federation with civil society institutions in the field of combating corruption. Monitoring law enforcement, 4, 25-31.

Kochurova, I.G. (2017). Anti-corruption in the Republic of Tatarstan. In the collection: "The State and the legal system of the Russian Federation in the conditions of the information society": a collection of articles of the International Scientific and Practical Conference. p. 34-38.

Korableva, O., Durand, T., Kalimullina, O., \& Stepanova, I. (2019). Usability testing of MOOC: Identifying user interface problems. Paper presented at the ICEIS 2019 - Proceedings of the 21st International Conference on Enterprise Information Systems, 2 468-475.

Kordík, M.; Kurilovská, L. (2018). Intra group compliance agreement as a tool to manage the risks in the daughter companies. Entrepreneurship and Sustainability Issues, 5(4), 1008-1019. http://doi.org/10.9770/jesi.2018.5.4(21)

Lipatov, V.A., Naimzada, M.D.Z., Denisov, A.A., Terekhov, A.G. (2017) The results of a sociological opinion poll on the level of corruption in the Kursk region. In the collection: "Scientific basis for the development and application of anti-corruption measures": a collection of scientific papers based on the materials of the regional forum "Youth. The science. Innovations" in the Regional Scientific and Practical Conference "Anti-Corruption in Modern Society". p. 24-34.

Luzgina, A. (2017). Problems of corruption and tax evasion in construction sector in Belarus. Entrepreneurship and Sustainability Issues, 5(2): 263-282. http://doi.org/10.9770/jesi.2017.5.2(8)

Malyutina, A.A. (2015) Formation of a mechanism for managing the sustainable development of municipal socio-economic systems in the region. Bulletin of the Samara Municipal Institute of Management, 3, 52-60.

Mullins, R. (2019). Using Dewey’s Conception of Democracy to Problematize the Notion of Disability in Public Education. Journal of Culture and Values in Education, 2(1), 1-17. Retrieved from http://cultureandvalues.org/index.php/JCV/article/view/24

Nagimov, A.M., Nagimov, M.A. (2015) State of corruption in government bodies in the Republic of Tatarstan: analysis of public opinion. In the collection: "Corruption: the state of counteraction and the direction of optimization of the struggle": Russian Criminological Association. p. 228-235.

Naushad, M., Faridi, M.R., Malik, S., A. (2018). Economic development of community by entrepreneurship: an investigation of the entrepreneurial intent and the institutional support to the local community in Al-Kharj region. Entrepreneurship and Sustainability Issues, 5(4), 899-913. http://doi.org/10.9770/jesi.2018.5.4(14)

Osipov, G.V., Glotov, V.I., Karepova, S.G. 2018. Population in the shadow market: petty corruption and unpaid taxes. Entrepreneurship and Sustainability Issues, 6(2), 692-710. http://doi.org/10.9770/jesi.2018.6.2(16)

Pankratov, A.Yu. (2011) Monitoring of corruption and implementation of anti-corruption policies in the Republic of Tatarstan: theory and practice. Actual problems of economics and law, 3(19), 255-259.

Papakostas, A. (2016) Formation of a civilized public sphere distrust, trust and corruption. Monitoring public opinion: economic and social changes, 1(131), 346-362. 


\section{ENTREPRENEURSHIP AND SUSTAINABILITY ISSUES}

ISSN 2345-0282 (online) http://jssidoi.org/jesi/ 2019 Volume 7 Number 1 (September) http://doi.org/10.9770/jesi.2019.7.1(48)

Pavlyuk, A. V., Kokorev, A. S., Lazareva, T. G., \& Artemova, E. I. (2018). Assessment of the economic security of the region (on the example of Chelyabinsk region). Journal of Applied Economic Sciences, 13(8), 2309-2322.

Petukhov, A. A., Dar'in, A. A., \& Telyakov, N. M. (2017). Processing of ferromanganese nodules of the Pacific Ocean. Metallurgist, 61(56), 439-443. https://doi.org/10.1007/s11015-017-0514-9

Ponomareva, N., Zvereva, A., Golubtsova, E., Novikova, E., \& Maximov, D. (2019). Approaches to the improvement of tax auditing for operations with intellectual property in the Russian Federation. Espacios, 40(10)

Poltaradneva, E.V., Goverdovskaya, I.N. (2014) Corruption in society: a sociological approach to the problem. In the collection: "Development of the institute of managerial personnel reserve in the constituent entities of the Russian Federation as a challenge of time and an effective tool for improving state personnel policy": collection of articles of the Interregional Scientific and Practical Conference (October 9, 2014, Samara). Samara, p. 284-289.

Prodanova, N. A., Plaskova, N. S., Bochkareva, N. G., Babalykova, I. A., Gazizyanova, Y. Y., \& Zherelina, O. N. (2019a). Integrated Corporate Reporting as An Innovative Business Reporting Model. International Journal of Engineering and Advanced Technology, 8(5), 2075-2078.

Prodanova, N. A., Trofimova, L. B., Adamenko, A. A., Erzinkyan, E. A., Savina, N. V., \& Korshunova, L. N. (2019b). Methodology for assessing control in the formation of financial statements of a consolidated business. International Journal of Recent Technology and Engineering, 8(1), 2696-2702.

Pujiyono, Setiawan, F. A., \& Hutabarat, D. M. T. (2019). A new approach to preventing corruption in indonesia: A study of the TP4 in central java, indonesia. Journal of Social Studies Education Research, 10(1), 93-115.

Saltykova, O.P. (2018) Prevention of corruption in the context of public policy. Bulletin of the Volga Institute of Management. 18(1), 6471.

Savchenko, I.A., Snegireva, L.A., Ustinkin, S.V. (2018) Causes of corruption in the cross-methodological dimension. Power, 26(5), 35-39.

Sasongko, G., Huruta, A.D., Wardani, A. (2019). Does the Wagner's Law exist in a strategic national area? An evidence from Kedungsepur - Indonesia. Insights into Regional Development, 1(2), 99-117. https://doi.org/10.9770/ird.2019.1.2(2)

Sharafutdinov, R. I., Polyakova, A. G., Gerasimov, V. O., Shpakova, R. N., \& Mikhailova, M. V. (2019). Inclusive growth: A dataset on key and institutional foundations for inclusive development of Russian regions. Data in Brief, 23. https://doi.org/10.1016/j.dib.2019.103864

Shumakova, O., Poltarykhin, A. L., \& Mozzherina, T. G. (2016). Import substitution as the basis of solving problem related to food safety of the russian federation. International Journal of Applied Business and Economic Research, 14(9), 5911-5920.

Temnikov, E.G. (2017) Anti-corruption education in the Republic of Tatarstan. In the collection: "Bulletin of scientific works" Yurist": based on the materials of the meeting of the I Council of youth public organizations and associations of the Republic of Tatarstan in the field of combating corruption. Ed. I.Sh. Mukhametzyanova, S.L. Alekseeva, R.N. Shaydullina. p. 19-23.

Tvaronavičienė, M. (2018). Towards sustainable and secure development: energy efficiency peculiarities in transport sector. Journal of Security and Sustainability Issues, 7(4), 719-725. https://doi.org/10.9770/jssi.2018.7.4(9)

Vlasenko, M.A. (2015) Features of the anti-corruption policy of modern Russia. Caspian region: politics, economy, culture, 3(44), 167-173.

Volkonskaya, E.K. (2018) Criminological assessment of the current situation related to corruption crimes in Russia. LexRussica, 4(137), 121-135.

Voronkova, O. Y., Iakimova, L. A., Frolova, I. I., Shafranskaya, C. I., Kamolov, S. G., \& Prodanova, N. A. (2019). Sustainable development of territories based on the integrated use of industry, resource and environmental potential. International Journal of Economics and Business Administration, 7(2), 151-163.

Yeparkhina, O.V. (2013). Modeling Corruption. Yaroslavl Pedagogical Gazette, 1(1), 110-116.

Zeibote, Z., Volkova, T., Todorov, K. (2019). The impact of globalization on regional development and competitiveness: cases of selected regions, Insights into Regional Development 1(1): 33-47. https://doi.org/10.9770/ird.2019.1.1(3) 


\section{ENTREPRENEURSHIP AND SUSTAINABILITY ISSUES}

ISSN 2345-0282 (online) http://jssidoi.org/jesi/ 2019 Volume 7 Number 1 (September) http://doi.org/10.9770/jesi.2019.7.1(48)

Zhang, H., Song, Y., Tan, S., Xia, S., Zhang, H., Jiang, C., . . Lv, Y. (2019). Anti-corruption efforts, public perception of corruption, and government credibility in the field of real estate: An empirical analysis based on twelve provinces in China. Cities, 90, 64-73. https://doi.org/10.1016/i.cities.2019.01.042

Zhuravlev, P. V., Poltarykhin, A. L., Alkhimenko, O. N., \& Kuksova, O. D. (2018). Human capital and its efficiency in the knowledge economy: The role of continuing education. Espacios, 39(46)

Irina FROLOVA is the PhD (Sociology), Associate Professor, Deputy Director on scientific work Kazan Innovative University named after V.G. Timiryasov, Kazan, Russia. Research interests: entrepreneurship and regional development; innovation and small firms; small firm internationalization; sustainability.

ORCID ID: orcid.org/0000-0002-8707-6336

Olga VORONKOVA, Doctor of Economic Sciences, Professor of management, business organization and innovation Department, Altai state University. Has the status of an expert of the Eurasian technological platform "Technologies of food and processing industry of agriculture - healthy food". Research interests - sustainable development of territories, innovation, technological and social entrepreneurship, "green" economy.

ORCID ID: orcid.org/0000-0002-3106-4643

Natalia ALEKHINA - Ph.D. of economics, Associate Professor at the Department of regulatory affairs in the sphere of drugs products and medical devices at Federal State Autonomous Educational Institution of Higher Education I.M. Sechenov First Moscow State Medical University of the Ministry of Health of the Russian Federation. Research interests - economics, macroeconomics, world economy, pharmaceuticals, pharmacoeconomics, medicines, medical devices, regional development, crisis management, business economics, statistics and analytics.

ORCID ID: orcid.org/0000-0002-0356-7200

Irina KOVALEVA, Doctor of Economic Sciences, Professor, Department of management, Altay State Agrarian University. Research interests - Development of region and Agricultural brunch, Marketing research, logistics.

ORCID ID: orcid.org/0000-0002-3184 5642 


\section{ENTREPRENEURSHIP AND SUSTAINABILITY ISSUES}

ISSN 2345-0282 (online) http://jssidoi.org/jesi/ 2019 Volume 7 Number 1 (September) http://doi.org/10.9770/jesi.2019.7.1(48)

Natalia PRODANOVA - Doctor of Economic Sciences, Professor, Basic department Financial Control, Analysis and Audit of the Main Control Department of Moscow, Plekhanov Russian University of Economics.

Research interests - accounting, integrated reporting, financial control, control and audit in the field of procurement ORCID ID: orcid.org/0000-0001-5140-2702

Liudmila KASHIRSKAYA, Doctor of Economic Sciences, Professor of the accounting, analysis and audit department of the Financial University under the Government of the Russian Federation

Research interests - accounting expertise, state financial control, budgetary establishments, departmental interaction, efficiency of activity.

ORCID ID: orcid.org/0000-0002-0234-0223

Register for an ORCID ID:

https://orcid.org/register

Copyright (C) 2019 by author(s) and VsI Entrepreneurship and Sustainability Center

This work is licensed under the Creative Commons Attribution International License (CC BY).

http://creativecommons.org/licenses/by/4.0/

cC) (i) Open Access 